\title{
Dietary Intervention of Betaine Hydrochloride on Nutrient Utilization in Broilers
}

\author{
D. Desinguraja*, K. Shyama and K. Ally \\ Department of Animal Nutrition, College of Veterinary and Animal Sciences, Mannuthy, \\ Thrissur - 680 651, Kerala, India \\ *Corresponding author
}

\section{A B S T R A C T}

Keywords

Betaine

Hydrochloride,

Nutrient Utilization

in Broiler

Article Info

Accepted:

20 March 2020

Available Online:

10 April 2020
As broiler production is characterized by a very short life cycle. the aim of study to know the effect of dietary supplementation of betaine hydrochloride (betaine $\mathrm{HCl}$ ) on nutrient utilization in broiler chicken for six weeks. One hundred - and ninety two, day-old commercial (Vencobb 400) broiler chicks were allotted to four groups, with four replications of 12 chicks each, randomly. The four groups were allotted in to four dietary regimes and each replicate was randomly assigned to one of the four dietary treatments in this study. The experimental feed was formulated according to BIS (1992) specifications and the control ration - $\mathrm{T}_{1}$ (without betaine) and feed grade betaine $\mathrm{HCl}$ at 250,500, $750 \mathrm{ppm}$ was added respectively to form different rations $T_{2}, T_{3}$ and $T_{4}$ groups. The result proven availability of crude protein, had significant difference $(\mathrm{P}<0.01)$ among dietary supplementation of betaine $\mathrm{HCl}$ treatments but availability of other nutrients, minerals and nitrogen balance didnot show any significant difference $(\mathrm{P}>0.05)$. This is to conclude that apparent nutrient digestibility of crude protein was higher for ration with betaine $\mathrm{HCl}$ at $750 \mathrm{ppm}$.

\section{Introduction}

Betaine $\mathrm{HCl}$ the synthetic form of betaine was cheeper than that of anhydrous betaine and hence could be used in broiler nutrition effectively due to the increased availability throughout the year. Phillip (2012) noted that, in the gut, above $\mathrm{pH} 3$ all added betaine $\mathrm{HCl}$ were present as anhydrous betaine and below $\mathrm{pH} 3$ as betaine $\mathrm{HCl}$ and concluded that whichever form of betaine was added, in the gastro intestinal tract the forms will be interchanged depending on $\mathrm{pH}$. Creswell and Srinongkote (2011) compared the effect of natural betaine and betaine $\mathrm{HCl}$ in broiler diet and concluded that both the sources of betaine had similar effects at equi-molar concentration.

\section{Materials and Methods}

The nutrient utilization of betaine $\mathrm{HCl}$ 
supplemented broilers were evaluated based on their performance and assay of biological materials. Straight run commercial broiler chicks (Vencobb-400) were utilized in the biological trial, from day old to six weeks of age. One hundred - and - ninety two, day-old Vencobb - 400 strain commercial broiler chicks were used as the experimental birds. The birds were allotted to four dietary treatment groups, with four replications of 12 chicks each randomly in a Completely Randomized Design.

The experimental feed (in mash form) was formulated using corn and soyabean meal as per BIS (1992) specifications. To the control ration $\left(\mathrm{T}_{1}\right)$, feed grade betaine $\mathrm{HCl}$ was added at $250,500,750 \mathrm{ppm}$ to formulate rations $\mathrm{T}_{2}$, $\mathrm{T}_{3}$ and $\mathrm{T}_{4}$ respectively, taking special care for proper mixing of betaine $\mathrm{HCl}$. No growth promoting antibiotics was added to any rations.

Broiler starter ration were fed up to four weeks of age and then switched over to broiler finisher ration for the last two weeks. Taking special care for proper mixing of betaine $\mathrm{HCl}$. No growth promoting antibiotics was added to any rations. The birds were provided with feed and water ad libitum. Feed consumption by the birds in each replicate, was calculated weekly. The rations were subjected to proximate analysis as per A.O.A.C., 1990. The chemical composition of the experimental broiler starter and finisher rations are presented in Table.1. Gross energy of experimental rations were estimated using bomb calorimeter. (Plain jacket calorimeter, model: 1341, Parr instruments co., USA).

To assess the nutrient utilization and balance of nitrogen a metabolism study was conducted for three days duration after the feeding trial by using four randomly selected birds from each treatment. The first two days served as an adaptation period during which they were fed the same feed. Birds were housed in individual metabolism cages with facilities for feeding, watering and faces collection. Water was provided ad libitum. During trial feed intake was recorded for each bird and excreta from each bird was collected by placing plastic sheet in faces collection tray for each replicate. Total amount of droppings voided in 24 hour by the birds of each replicate was collected from the plastic sheets and measured. These samples were placed in double lined polyethylene bags, sealed, labeled and kept in deep freezer at $20^{\circ} \mathrm{C}$ until further analysis. At the end of the metabolism trial the daily samples were pooled together and one part of the sample was used for estimation of faecal nitrogen (N) content. Rest of the faecal sample was dried at $65^{\circ} \mathrm{C}$ for $48 \mathrm{~h}$ in a hot air oven, ground and stored in polyethylene sachets till analyzed further for proximate components.

The data collected on various parameters were statistically analyzed by Completely Randomized Design (CRD) as per the methods of Snedecor and Cochran (1994) and the means of different experimental groups were also tested by using Duncan's Multible Range Test (DMRT) using SPSS Ver. 20.0.

\section{Results and Discussion}

The chemical and mineral compositions of the droppings voided by experimental birds during the metabolic trial are given in Table 2.

The average DM per cent of droppings were $21.55,22.19,17.93$ and 17.72 for the treatment groups belonging to $\mathrm{T}_{1}, \mathrm{~T}_{2}, \mathrm{~T}_{3}$ and $\mathrm{T}_{4}$ respectively. The $\mathrm{CP}$ and $\mathrm{GE}$ ( $\mathrm{kcal} / \mathrm{kg}$ ) contents of the droppings of birds belonging to groups fed with rations $\mathrm{T}_{1}, \mathrm{~T}_{2}, \mathrm{~T}_{3}$ and $\mathrm{T}_{4}$ were $27.00,25.17,26.55$ and 26.68 per cent and 3962.70, 3977.56, 3924.30 and 3918.71 respectively. 
The calcium content of the droppings of bird belonging to groups maintained on rations $T_{1}$, $\mathrm{T}_{2}, \mathrm{~T}_{3}$ and $\mathrm{T}_{4}$ were $2.08,1.91,2.11$ and 2.22 per cent and phosphorus contents were 1.07, 0.99, 1.04 and 1.07 per cent respectively.

Data on nutrient digestibility percentage of experimental rations $T_{1}, T_{2}, T_{3}$ and $T_{4}$ are presented in Table 9. The percentage availability of the four experimental rations $\mathrm{T}_{1}, \mathrm{~T}_{2}, \mathrm{~T}_{3}$ and $\mathrm{T}_{4}$ were $68.04,66.79,68.55$ and 68.82 for DM, 58.12, 59.34, 59.65 and 60.81 for $\mathrm{CP}, 81.97,83.26,84.16$ and 85.46 for $\mathrm{EE}, 37.99,37.15,36.93$ and 35.27 for $\mathrm{CF}$, $78.76,75.80,79.52$ and 79.28 for NFE and $68.29,67.12,68.47$ and 69.33 for energy.

The nitrogen balance for the experimental birds fed four dietary treatments $\mathrm{T}_{1}, \mathrm{~T}_{2}, \mathrm{~T}_{3}$ and $\mathrm{T}_{4}$ were 1.96, 2.25, 2.38 and $1.86 \mathrm{~g} /$ day respectively data are given in Table 3 .
The statistical analysis of data on availability of nutrients (DM, EE, CF, NFE and energy) not differ significantly between the treatment groups by inclusion of different levels of betaine $\mathrm{HCl}$ in broiler diets but the $\mathrm{CP}$ availability was higher $(\mathrm{p}<0.01)$ in all three betaine $\mathrm{HCl}$ supplemented rations than the control ration without betaine $\mathrm{HCl}$.

The present data obtained for the betaine $\mathrm{HCl}$ supplemented group is in the agrement with the findings of Attia et al., (2005) in broilers who observed that the addition of betaine had no significant influence on digestibility of DM, EE and CF except CP and Nguyen et al., (2014) also observed that betaine supplementation did not have any impact on energy measures like apparent metabolisable energy (AME) and net energy (NE) in broilers.

Table.1a Chemical and mineral composition of broiler starter rations, \%

\begin{tabular}{|l|c|c|c|c|}
\hline \multirow{2}{*}{ Parameters } & \multicolumn{4}{|c|}{ Treatments* (broiler starter rations) } \\
\hline Dry matter & $\mathrm{T} 1$ & $\mathrm{~T} 2$ & $\mathrm{~T} 3$ & $\mathrm{~T} 4$ \\
\hline Organic dry matter & 91.34 & 91.12 & 91.43 & 91.84 \\
\hline Crude protein & 92.05 & 92.3 & 92.07 & 92.71 \\
\hline Ether extract & 23.18 & 23.12 & 23.08 & 23.35 \\
\hline Crude fibre & 3.16 & 3.14 & 3.21 & 3.36 \\
\hline Total ash & 2.82 & 2.74 & 2.93 & 2.86 \\
\hline Acid insoluble ash & 1.95 & 7.70 & 7.93 & 7.29 \\
\hline Nitrogen free & 62.89 & 1.12 & 1.17 & 1.12 \\
\hline extract & & 63.30 & 62.85 & 63.14 \\
\hline GE, kcal/kg & 3822.01 & 3838.02 & 3788.47 & 3805.99 \\
\hline Calcium & 1.24 & 1.26 & 1.23 & 1.22 \\
\hline Total phosphorus & 0.69 & 0.67 & 0.72 & 0.69 \\
\hline ME** (kcal/kg) & 2800 & 2800 & 2800 & 2800 \\
\hline
\end{tabular}


Table.1b Chemical and mineral composition of broiler finisher rations, \%

\begin{tabular}{|l|c|c|c|c|}
\hline \multirow{2}{*}{ Parameters } & \multicolumn{4}{|c|}{ Treatments* (broiler finisher rations) } \\
\hline Dry matter & $\mathrm{T} 1$ & $\mathrm{~T} 2$ & $\mathrm{~T} 3$ & $\mathrm{~T} 4$ \\
\hline Organic dry matter & 91.04 & 91.07 & 91.31 & 91.20 \\
\hline Crude protein & 92.53 & 92.3 & 92.39 & 92.44 \\
\hline Ether extract & 20.51 & 20.46 & 20.53 & 20.48 \\
\hline Crude fibre & 3.86 & 3.76 & 3.87 & 3.87 \\
\hline Total ash & 3.11 & 2.99 & 3.15 & 3.18 \\
\hline Acid insoluble ash & 7.47 & 7.70 & 7.61 & 7.56 \\
\hline Nitrogen free extract & 1.30 & 1.14 & 1.34 & 1.39 \\
\hline GE, kcal/kg & 65.05 & 65.09 & 64.84 & 64.91 \\
\hline Calcium & 3993.37 & 4015.66 & 3916.80 & 3981.59 \\
\hline Total phosphorus & 1.21 & 1.21 & 1.23 & 1.30 \\
\hline ME** (kcal/kg) & 0.70 & 0.69 & 0.68 & 0.68 \\
\hline
\end{tabular}

*On dry matter basis

** Calculated values.

Table.2 Chemical composition of the droppings voided by birds maintained on four experimental rations, $\%$

\begin{tabular}{|c|c|c|c|c|}
\hline \multirow[t]{2}{*}{ Parameters $^{1}$} & \multicolumn{4}{|c|}{ Treatments* } \\
\hline & $\mathrm{T} 1$ & $\mathrm{~T} 2$ & T3 & $\mathrm{T} 4$ \\
\hline Dry matter & $\begin{array}{l}21.55 \\
\pm 1.69\end{array}$ & $\begin{array}{l}22.19 \\
\pm 1.62\end{array}$ & $\begin{array}{r}17.93 \\
\pm 1.66\end{array}$ & $\begin{array}{l}17.72 \\
\pm 1.87\end{array}$ \\
\hline Organic dry matter & $\begin{array}{l}78.27 \\
\pm 0.34\end{array}$ & $\begin{array}{l}80.06 \\
\pm 0.28\end{array}$ & $\begin{array}{l}76.77 \\
\pm 0.75\end{array}$ & $\begin{array}{l}76.98 \\
\pm 1.37\end{array}$ \\
\hline Crude protein & $\begin{array}{l}27.00 \\
\pm 1.04\end{array}$ & $\begin{array}{l}25.17 \\
\pm 0.95\end{array}$ & $\begin{array}{l}26.55 \\
\pm 1.31\end{array}$ & $\begin{array}{l}26.68 \\
\pm 3.01\end{array}$ \\
\hline Ether extract & $\begin{array}{c}2.18 \\
\pm 0.09\end{array}$ & $\begin{array}{c}1.90 \\
\pm 0.10\end{array}$ & $\begin{array}{c}1.92 \\
\pm 0.21\end{array}$ & $\begin{array}{c}1.79 \\
\pm 0.04\end{array}$ \\
\hline Crude fibre & $\begin{array}{c}6.08 \\
\pm 0.30\end{array}$ & $\begin{array}{c}5.69 \\
\pm 0.24\end{array}$ & $\begin{array}{c}6.36 \\
\pm 0.30\end{array}$ & $\begin{array}{c}6.87 \\
\pm 0.84\end{array}$ \\
\hline Total ash & $\begin{array}{l}21.73 \\
\pm 0.34\end{array}$ & $\begin{array}{l}19.94 \\
\pm 0.28\end{array}$ & $\begin{array}{l}23.23 \\
\pm 0.75\end{array}$ & $\begin{array}{l}23.02 \\
\pm 1.37\end{array}$ \\
\hline Acid insoluble ash & $\begin{array}{c}3.92 \\
\pm 0.05\end{array}$ & $\begin{array}{l}4.03 \\
\pm 0.30\end{array}$ & $\begin{array}{l}4.51 \\
\pm 0.37\end{array}$ & $\begin{array}{c}4.63 \\
\pm 0.39\end{array}$ \\
\hline $\begin{array}{l}\text { Nitrogen free } \\
\text { extract }\end{array}$ & $\begin{array}{l}43.01 \\
\pm 1.73\end{array}$ & $\begin{array}{l}47.30 \\
\pm 1.08\end{array}$ & $\begin{array}{l}41.95 \\
\pm 1.92\end{array}$ & $\begin{array}{l}41.64 \\
\pm 4.90\end{array}$ \\
\hline GE of faeces, kcal $/ \mathrm{kg}$ & $\begin{array}{l}3962.70 \\
\pm 38.13\end{array}$ & $\begin{array}{l}3977.56 \\
\pm 22.92\end{array}$ & $\begin{array}{l}3924.30 \\
\pm 47.83\end{array}$ & $\begin{array}{l}3918.71 \\
\pm 19.27\end{array}$ \\
\hline Calcium & $\begin{array}{c}2.08 \\
\pm 0.17\end{array}$ & $\begin{array}{c}1.91 \\
\pm 0.19\end{array}$ & $\begin{array}{c}2.11 \\
\pm 0.13\end{array}$ & $\begin{array}{c}2.22 \\
\pm 0.26\end{array}$ \\
\hline Phosphorus & $\begin{array}{c}1.07 \\
\pm 0.02\end{array}$ & $\begin{array}{c}0.99 \\
\pm 0.03\end{array}$ & $\begin{array}{c}1.04 \\
\pm 0.03\end{array}$ & $\begin{array}{c}1.07 \\
\pm 0.03\end{array}$ \\
\hline
\end{tabular}

*on dry matter basis

${ }^{1}$ Each value is a mean of 4 observations with SE 
Table.3 Apparent Nutrient digestibility of four experimental rations (\%) and nitrogen balance ( $\mathrm{g} /$ day) of birds maintained on four experimental rations

\begin{tabular}{|c|c|c|c|c|c|c|}
\hline \multirow[t]{2}{*}{ Parameters } & \multicolumn{4}{|c|}{ Treatments $^{1}$} & \multirow[b]{2}{*}{ F Value } & \multirow[b]{2}{*}{ P Value } \\
\hline & $\mathrm{T} 1$ & $\mathrm{~T} 2$ & T3 & $\mathrm{T} 4$ & & \\
\hline Dry matter & $\begin{array}{l}68.04 \\
\pm 1.39\end{array}$ & $\begin{array}{l}66.79 \\
\pm 1.44\end{array}$ & $\begin{array}{l}68.55 \\
\pm 1.68\end{array}$ & $\begin{array}{l}68.82 \\
\pm 3.25\end{array}$ & $0.186^{\mathrm{ns}}$ & 0.904 \\
\hline Organic matter & $\begin{array}{l}72.95 \\
\pm 1.29\end{array}$ & $\begin{array}{r}71.20 \\
\pm 1.22\end{array}$ & $\begin{array}{r}73.85 \\
\pm 1.54\end{array}$ & $\begin{array}{r}73.93 \\
\pm 3.05\end{array}$ & $0.431^{\mathrm{ns}}$ & 0.734 \\
\hline Crude protein & $\begin{array}{l}58.12^{\mathrm{a}} \\
\pm 0.42\end{array}$ & $\begin{array}{l}59.34^{\mathrm{b}} \\
\pm 0.27\end{array}$ & $\begin{array}{l}59.65^{b} \\
\pm 0.28\end{array}$ & $\begin{array}{l}60.81^{\mathrm{c}} \\
\pm 0.21\end{array}$ & $\begin{array}{c}13.129 * \\
*\end{array}$ & 0.001 \\
\hline Ether extract & $\begin{array}{l}81.97 \\
\pm 0.52\end{array}$ & $\begin{array}{l}83.26 \\
\pm 1.10\end{array}$ & $\begin{array}{l}84.16 \\
\pm 2.65\end{array}$ & $\begin{array}{l}85.46 \\
\pm 1.81\end{array}$ & $0.737^{\mathrm{ns}}$ & 0.550 \\
\hline Crude fiber & $\begin{array}{l}37.99 \\
\pm 0.76\end{array}$ & $\begin{array}{l}37.15 \\
\pm 1.38\end{array}$ & $\begin{array}{l}36.93 \\
\pm 0.83\end{array}$ & $\begin{array}{l}35.27 \\
\pm 0.73\end{array}$ & $1.392^{\mathrm{ns}}$ & 0.293 \\
\hline $\begin{array}{l}\text { Nitrogen free } \\
\text { extract }\end{array}$ & $\begin{array}{r}78.76 \\
\pm 1.77\end{array}$ & $\begin{array}{r}75.80 \\
\pm 1.60\end{array}$ & $\begin{array}{r}79.52 \\
\pm 2.02\end{array}$ & $\begin{array}{r}79.28 \\
\pm 4.20\end{array}$ & $0.433^{\mathrm{ns}}$ & 0.733 \\
\hline Energy efficiency & $\begin{array}{l}68.29 \\
\pm 1.31 \\
\end{array}$ & $\begin{array}{l}67.12 \\
\pm 1.34 \\
\end{array}$ & $\begin{array}{r}68.47 \\
\pm 1.86\end{array}$ & $\begin{array}{l}69.33 \\
\pm 3.14 \\
\end{array}$ & $0.196^{\mathrm{ns}}$ & 0.897 \\
\hline Nitrogen balance & $\begin{array}{c}1.96 \\
\pm 0.13\end{array}$ & $\begin{array}{c}2.25 \\
\pm 0.06\end{array}$ & $\begin{array}{r}2.38 \\
\pm 0.08\end{array}$ & $\begin{array}{c}1.86 \\
\pm 0.39\end{array}$ & $1.325^{\mathrm{ns}}$ & 0.312 \\
\hline
\end{tabular}

${ }^{1}$ Each value is a mean of 4 observations with SE

ns - non significant $(\mathrm{P}>0.05)$

**Means bearing different superscripts within same column differ significantly $(\mathrm{P} \leq 0.01)$

Table.4 Mineral availability of four experimental rations, $\%$

\begin{tabular}{|c|c|c|c|c|c|c|}
\hline \multirow[t]{2}{*}{ Parameters } & \multicolumn{4}{|c|}{ Treatments $^{1}$} & \multirow[b]{2}{*}{ F value } & \multirow[b]{2}{*}{$\begin{array}{c}\mathbf{P} \\
\text { Value }\end{array}$} \\
\hline & $\mathrm{T} 1$ & $\mathrm{~T} 2$ & $\mathrm{~T} 3$ & $\mathrm{~T} 4$ & & \\
\hline Calcium & $\begin{array}{l}44.86 \\
\pm 6.36\end{array}$ & $\begin{array}{l}47.30 \\
\pm 7.27\end{array}$ & $\begin{array}{l}45.61 \\
\pm 5.82\end{array}$ & $\begin{array}{l}48.50 \\
\pm 1.78\end{array}$ & $0.083^{\mathrm{ns}}$ & 0.968 \\
\hline Phosphorus & $\begin{array}{l}51.28 \\
\pm 1.75\end{array}$ & $\begin{array}{l}52.42 \\
\pm 2.02\end{array}$ & $\begin{array}{l}51.99 \\
\pm 1.33\end{array}$ & $\begin{array}{l}50.83 \\
\pm 4.92\end{array}$ & $0.061^{\mathrm{ns}}$ & 0.979 \\
\hline
\end{tabular}

${ }^{1}$ Each value is a mean of 4 observations with SE ns - non significant $(\mathrm{P}>0.05)$

On contrary to this EI-Husseiny et al., (2007) observed improved digestibility of organic matter, crude protein, ether extract, crude fiber and nitrogen-free extract with increasing levels of dietary betaine supplementation in broiler rations.

The per cent availability of minerals of rations $\mathrm{T}_{1}, \mathrm{~T}_{2}, \mathrm{~T}_{3}$ and $\mathrm{T}_{4}$ were $44.86,47.30,45.61$ and 48.50 for calcium, 51.28, 52.42, 51.99 and
50.83 for phosphorus. However, statistical analysis of data revealed that there was no significant difference in minerals availability among treatment rations for calcium and phosphorus. (Table 4)

Statistical analysis of data on availability of nutrients with inclusion of different levels of betaine $\mathrm{HCl}$ in broiler diet reveled increased the availability of $\mathrm{CP}(\mathrm{P}<0.01 \%)$ than the 
control group. The nitrogen balance (g/ day) of four treatment groups were 1.96, $2.25,2.38$ and 1.86 , respectively and there was no significant difference $(\mathrm{P}>0.05)$ among the treatment groups.

In conclusion, this study found that supplementation of betaine $\mathrm{HCl}$ at $750 \mathrm{ppm}$ improves nutrient digestability of crude protein, which in turn may increase the broiler production in short cycle. Hence inclusion of betaine in commercial ration may be recommended for better production.

\section{Acknowledgment}

The authors are very much obliged to the Department of Animal Nutrition, College of Veterinary and Animal Sciences, Mannuthy, Kerala for offering appropriate facilities required conducting this research work.

\section{Conflict of Interest}

The authors declare that they have no conflict of interest.

\section{Ethical approval}

The animal studies for the experiment have been approved by the ethics committeeCOVAS, Mannuthy, Kerala and therefore have been performed in accordance with the ethics standards as applicable under institutional guidelines."

\section{References}

AOAC, 1990. Official Methods of Analysis.
Fifteenth edition. Association of Official Analytical Chemists, Washington, D. C. 587p

Attia, Y.A., Hassan, R.A., Shehatta, M.H. and Abd EI-Hady, S.B. 2005. Growth, carcass quality and serum constituents of slow growing chicks as affected by betaine addition to diets containing 2 . Different levels of methionine. Int. J. Poult. Sci., 4 (11): 856-865

Bureau of Indian Standards (BIS), 1992. Poultry Feeds Specification. Fourth revision. Bureau of Indian Standards, New Delhi. p.4

Creswell, D. and Srinongkote, S. 2011. Betaine for broilers. Asian Feed January / February 2011.

El-Husseiny, O.M., El-Ella, A.M.A., AbdElsamee, M.O. and Magda, M. AbdElfattah, 2007. Response of broilers performance to dietary betaine and folic acid at different methionine levels. Int. J. Poult. Sci., 6 (7): 515-523

Nguyen, H., Swick, R.A., Wu, S.B. and Choct, M. 2014. Betaine supplementation affects energy partitioning in broilers. Proceedings of $25^{\text {th }}$ annual australian poultry science symposium.16-19 February,2014. p107.

Phillip, A. 2012. Betaine as an osmolyte. Proceedings of $23^{\text {rd }}$ annual australian poultry science symposium. $19-22$ February, 2012.p.302

Snedecor, G. W. And Cochran, W.G. 1994. Statistical Methods, Iowa State University Press, Ames, I. A.

\section{How to cite this article:}

Desinguraja, D., K. Shyama and Ally, K. 2020. Dietary Intervention of Betaine Hydrochloride on Nutrient Utilization in Broilers. Int.J.Curr.Microbiol.App.Sci. 9(04): xx-Xx. doi: https://doi.org/10.20546/ijcmas.2020.904.378 